\title{
Immunoexpression of cell cycle regulators in canine prostate with proliferative lesions
}

\section{Imunoexpressão de reguladores do ciclo celular em próstatas caninas com alterações proliferativas}

\author{
Mariana Batista Rodrigues Faleiro ${ }^{\text {*; }}$, Danilo Rezende e Silva²; Rafael Malagoli \\ Rocha $^{3}$; Veridiana Maria Brianezi Dignani de Moura ${ }^{4}$
}

\begin{abstract}
Immunostaining of p21, p27, p53, cyclin D1, c-myc was evaluated in normal canine prostate and prostate with proliferative disorders to verify the interaction between these regulators of cell cycle progression. From 106 samples of canine prostate obtained from a TMA block, 15 were considered normal, 16 diagnosed as benign prostatic hyperplasia (BPH), 30 as proliferative inflammatory atrophy (PIA), 20 as prostatic intraepithelial neoplasia (PIN), and 25 as prostatic carcinoma (PC). There was positive correlation between p21 and p27 for number of stained cells and staining intensity in all conditions and between c-myc and p53 in prostates with PIN. Considering the number of labeled cells, there was positive correlation between $\mathrm{p} 21$ and p53 in the normal prostate. Relative to the intensity of staining, there was positive correlation between $\mathrm{p} 21$ and p53 in prostate tissue with PIN and between p 27 and c-myc in prostates with PIA. A negative correlation between c-myc and cyclin D1 was also identified in the glands with PIN, considering the number of labeled cells, and between p27 and c-myc in the prostates with PC for staining intensity. In conclusion, the expression of p21, p27, p53, cyclin D1 and c-myc varies according to type of proliferative lesion in canine prostate. Taken together, the results indicate low growth potential of the canine PC in the presence of p21 and p27 overexpression, cyclin D1 low expression and regular expression of c-myc, even with the expression of p53 mutant type. Further, it was possible reaffirm the premalignant potential of PIA and PIN in canine prostate.
\end{abstract}

Key words: C-myc. Cyclin D1. Benign prostatic hyperplasia. Proliferative inflammatory atrophy. Prostatic intraepithelial neoplasia. Prostatic carcinoma.

\section{Resumo}

\begin{abstract}
A imunomarcação de p21, p27, p53, ciclina D1 e c-myc foi avaliada na próstata canina normal e com desordens proliferativas para verificar quanto a interação desses reguladores na progressão do ciclo celular. Um total de 106 amostras de próstata canina foi obtido a partir de um bloco de TMA, sendo 15 normais, 16 hiperplasia prostática benigna (HPB), 30 atrofia inflamatória proliferativa (PIA), 20 neoplasia intraepitelial prostática (PIN), e 25 carcinoma prostático (PC). Foi encontrada diferença na imunomarcação de p21, p27, ciclina D1 e p53 no epitélio acinar em relação aos diagnósticos. Houve correlação positiva entre p21 e p27 para as variáveis número de células marcadas e intensidade de imunomarcação em todos os diagnósticos (normal, HPB, PIA, PIN e PC), e entre c-myc e p53 nas
\end{abstract}

1 Prof ${ }^{a}$, Faculdade União de Goyazes, FUG, Trindade, GO, Brasil. E-mail: marianafavet@hotmail.com

2 Prof., Faculdade Anhanguera de Anápolis, FAA, Anápolis, GO, Brasil. E-mail: drs-patovet@hotmail.com

3 Pesquisador, Hospital AC Camargo, São Paulo, SP, Brasil. E-mail: rafael.malagoli@gmail.com

${ }^{4}$ Prof ${ }^{a}$, Universidade Federal de Goiás, UFG, GO, Brasil. E-mail: vdmoura@hotmail.com

* Author for correspondence 
próstatas com PIN. De acordo com o número de células marcadas, houve correlação positiva entre p21 e p53 na próstata normal. De acordo com a intensidade de imunomarcação houve correlação positiva entre p21 e p53 no tecido prostático com PIN e entre p27 e c-myc em próstatas com PIA. Foi observada correlação negativa entre c-myc e ciclina D1 nas glândulas com PIN, considerando o número de células marcadas, e entre p27 e c-myc na próstata com PC, para a variável intensidade de imunomarcação. Conclui-se que a expressão de p21, p27, p53, ciclina D1 e c-myc varia na próstata canina de acordo com o tipo de lesão proliferativa. Em conjunto, os resultados indicam baixo potencial de crescimento dos carcinomas da próstata canina quando há superexpressão de p21 e de p27, baixa expressão de ciclina D1 e expressão normal de c-myc, mesmo com expressão de p53 tipo mutante. Ainda, considerando o imunofenótipo semelhante nas glândulas com PIA, PIN e PC no que se refere aos reguladores da progressão do ciclo celular, reitera-se o potencial pré-maligno da PIA e PIN na próstata canina.

Palavras-chave: C-myc. Ciclina D. Hiperplasia prostática benigna. Atrofia inflamatória proliferativa. Neoplasia intraepitelial prostática. Carcinoma prostático.

The major step in malignant transformation of the tumors is the uncontrolled cell cycle, and knowing the regulators is important to understand these malignant transformations (SANCHEZ; DYNLACHT, 2005). One of the important proteins that control the cell cycle is the p53 protein, known as the guardian of the genome. If an error occurs in DNA transcription, it will stop the cell cycle and activate repair mechanisms or trigger apoptotic events, to induce cell death. This occurs by stimulating $\mathrm{p} 21$ that has regulatory functions and blocks the cell cycle progression from G1-S phase through different steps (KIRKNESS et al., 2003). The p21 allow cell DNA repair, differentiation and apoptosis. These tasks are performed by the interaction with cyclin A-cyclin dependent kinase 2 (Cdk2), and cyclin D1-Cdk4 complexes (GARTEL; RADHAKRISHNAN, 2005).

Cyclin D1 (CD1) is the positive regulator of the G1 phase progression in the cell cycle, binds to and activates the cyclin-dependent kinases Cdk4 and Cdk6, regulate phosphorylation of the retinoblastoma gene $(\mathrm{Rb})$ product, thereby activating E2F transcription factors (COLOZZA et al., 2005). Also, the CD1 is down-regulated by c-myc factor (TAPIA et al., 2009). In dogs, CD1 is also overexpressed in mammary carcinoma, squamous cell carcinoma and basal cell carcinoma (SFACTERIA et al., 2003), but not in mast cell tumors (OZAKI et al., 2007). Another important cell cycle inhibitor is the p27 protein, which increasing levels result in blocking cell cycle at $\mathrm{S}$ phase. De Marzo et al. (1998) observed lower expression of p27 in lesions such as benign prostatic hyperplasia $(\mathrm{BPH})$, prostatic intraepithelial neoplastic (PIN), and prostatic carcinoma (PC), and concluded that this reduced expression contributes to the high rate of mitosis in these proliferative lesions.

The c-myc has been suggested as the key element of carcinogenesis in different tumors, with direct and indirect action in the regulation of the cell cycle and apoptosis (LOPES et al., 2010). Expression of c-myc has been found in different types of canine neoplasia, such as transmissible venereal tumors (TVT) (LIMA et al., 2016), mammary tumors (GAVHANE et al., 2013), and prostatic carcinoma (FONSECA-ALVES et al., 2013). In canine prostate, the expression of c-myc is elevated in tissues with proliferative inflammatory atrophy (PIA) and PC and has been associated with the loss of the tumor suppressor proteins NKX3.1 and E-cadherin (FONSECA-ALVES et al., 2013). To verify the interaction between the regulators of cell cycle progression in canine prostate with proliferative lesions, p21, p27, p53, ciclina D1 and c-myc immunostaining were evaluated in normal glands and with BPH, PIA, PIN and PC.

This research was approved by committee on publication ethics COPE/UFG number 353/2010. The prostatic samples were from adult dogs of pure or mixed breeds and normal prostatic tissues were 
from dogs with no lesions in the gland. Three- $\mu \mathrm{m}-$ sections were obtained from formalin-fixed-paraffinembedded (FFPE) tissue blocks and stained with hematoxylin and eosin (HE). Histomorphological evaluation included normal prostates and with BPH (FONSECA-ALVES et al., 2010), PIA (TOLEDO et al., 2010), PIN (BOSTWICK, 1995), and PC (LAI et al., 2008).

The prostate tissue microarray (TMA) was carried out according to Rubin et al. (2002). From the areas identified in the histomorphological evaluation, tissue cores of $1.0 \mathrm{~mm}$ were taken from FFPE tissue samples and arrayed on a recipient paraffin block using the tissue microarray (Beencher Instruments ${ }^{\circledR}$, Silver Spring, USA). Three- $\mu \mathrm{m}$-sections were obtained from recipient block and distended on charged slides (Starfrost ${ }^{\circledR}$ - Dako 9545-1) for HE and immunohistochemistry.
Immunohistochemistry was performed in TMA slides. The tissues were deparaffinized, rehydratated and washed in distilled water. Endogenous peroxidase and non-specific protein were blocked with 3\% hydrogen peroxide for $20 \mathrm{~min}$, and protein block (Leica, Newcastle, UK, \#RE7102) for 5 min at $37^{\circ} \mathrm{C}$, respectively. Antigen retrieval was performed with $10 \mathrm{mM}$ pre-heated citrate buffer, $\mathrm{pH}$ 6.0, for $3 \mathrm{~min}$, in pressure cooker (Solar, Rapid Express, Tramontina, Brazil). The samples were incubated with the primary antibodies (Table 1 ) overnight, at $4^{\circ} \mathrm{C}$, in a wet chamber. Incubation with polymer enzyme, chromogen and HRP substrate for signal detection were done using reagents from polymer kit (New Link Max Polymer, United Kingdom, \#RE7260-K) and following manufacturer's directions. Sections were counterstained with Mayer's hematoxylin, washed, dehydrated, cleared, coverslipped, and examined by light microscopy.

Table 1. Primary antibodies and their clone, host, dilution, brand and code used in the immunohistochemistry for the normal canine prostatic tissue and with BPH, PIA, PIN and PC.

\begin{tabular}{|c|c|c|c|c|}
\hline Primary Antibody & Clone & Host & Dilution & Brand and Code \\
\hline anti-p21 WAF1/Cip1 & SX118 & & $1: 50$ & Dako \#M7202 \\
\hline anti-p27 $7^{\text {Kip1 }}$ & SX53G8 & & $1: 200$ & Dako \#M7203 \\
\hline anti-p53 & $5 \mathrm{G} 176$ & Mouse & $1: 500$ & Santa Cruz Biotechnology \#sc-71785 \\
\hline anti-cyclin D1( & A12 & & $1: 50$ & Santa Cruz Biotechnology \#sc-8396 \\
\hline anti-C-MYC Ab-2 & 9E10.3 & & $1: 50$ & Thermo Fisher Scientific \#MS-139-P0 \\
\hline
\end{tabular}

Samples from human colon carcinoma for $\mathrm{p} 21$ and $\mathrm{p} 27$, human mammary carcinoma for $\mathrm{p} 53$, and canine lymph node to cyclin D1 and c-myc were used as positive control. For negative control the primary antibody was replaced by PBS buffer, $\mathrm{pH}$ 7.4. The intensity of p21, p27, p53, cyclin D1 and c-myc reactivity was scored as: $0=$ negative, $1=$ mild, $2=$ moderate and $3=$ intense. Regarding the number of stained cells, the scores were: $0=$ negative, $1=1$ $25 \%, 2=26-50 \%, 3=51-75 \%$ and $4=76-100 \%$.

The Chi-square, Kruskal-Wallis, nonparametric multiple comparison test for paired contrasts the relative effects with Tukey correction, as well as descriptive data were used to compare the scores of the percentage of positive cells and their intensity. Association between p21, p27, p53, cyclin D1and c-myc expression in normal prostatic tissue and with the different lesions studied was achieved by Spearman test. For all it was used SPSS (IBM Corp. Released 2010. IBM SPSS Statistics for Windows, Version 19.0. Armonk, NY: IBM Corp.) and R (R Development Core Team (2008) R Foundation for Statistical Computing, Vienna, Austria). The 5\% of significance level was considered. 
From TMA slide were obtained $15(14.15 \%)$ were normal tissues, 16 (15.10\%) BPH, 30 (28.30\%) PIA, 20 (18.87\%) PIN, and 25 (23.58\%) PC. The immunostaining was nuclear for p21, p27, and p53 (Figure 1), cytoplasmic for cyclin D1 and nuclear through cytoplasmic and membrane for c-myc (Figure 2).

The number of stained cells to p21 in normal prostatic tissue was different from those with PIN, as well as it was different in prostatic tissues with $\mathrm{BPH}$ from those with PIA, PIN and PC. According to intensity of expression, there were differences in normal prostatic tissue from those with PIA, $\mathrm{PIN}$ and PC, as well as it was different in prostatic tissues with BPH from those with PIA, PIN and PC $(\mathrm{p}<0.05$ - Table 2$)$.

Figure 1. Photomicrography of nuclear immunostaining. A) Canine PIN tissue with score three for labeling intensity and four for number of labeled cells for p21. B) Human colon carcinoma. Positive control for p21 with scores two for labeling intensity and four for number of labeled cells. C) Normal canine prostatic tissue with one for labeling intensity and one for number of labeled cells for p21. D) Canine PIN with score two for labeling intensity and two for number of labeled cells for p27. E) Human colon carcinoma. Positive control of p27 with score three for labeling intensity and four for number of labeled cells. F) Canine PIA with score three for labeling intensity and four for number of labeled cells for p53. G) Mammary carcinoma. Positive control of p53 with score three for labeling intensity and three for number of labeled cells. H) Normal canine prostatic tissue with zero score for p-53. IHC, DAB, and HE counterstain. 200x and 400x.
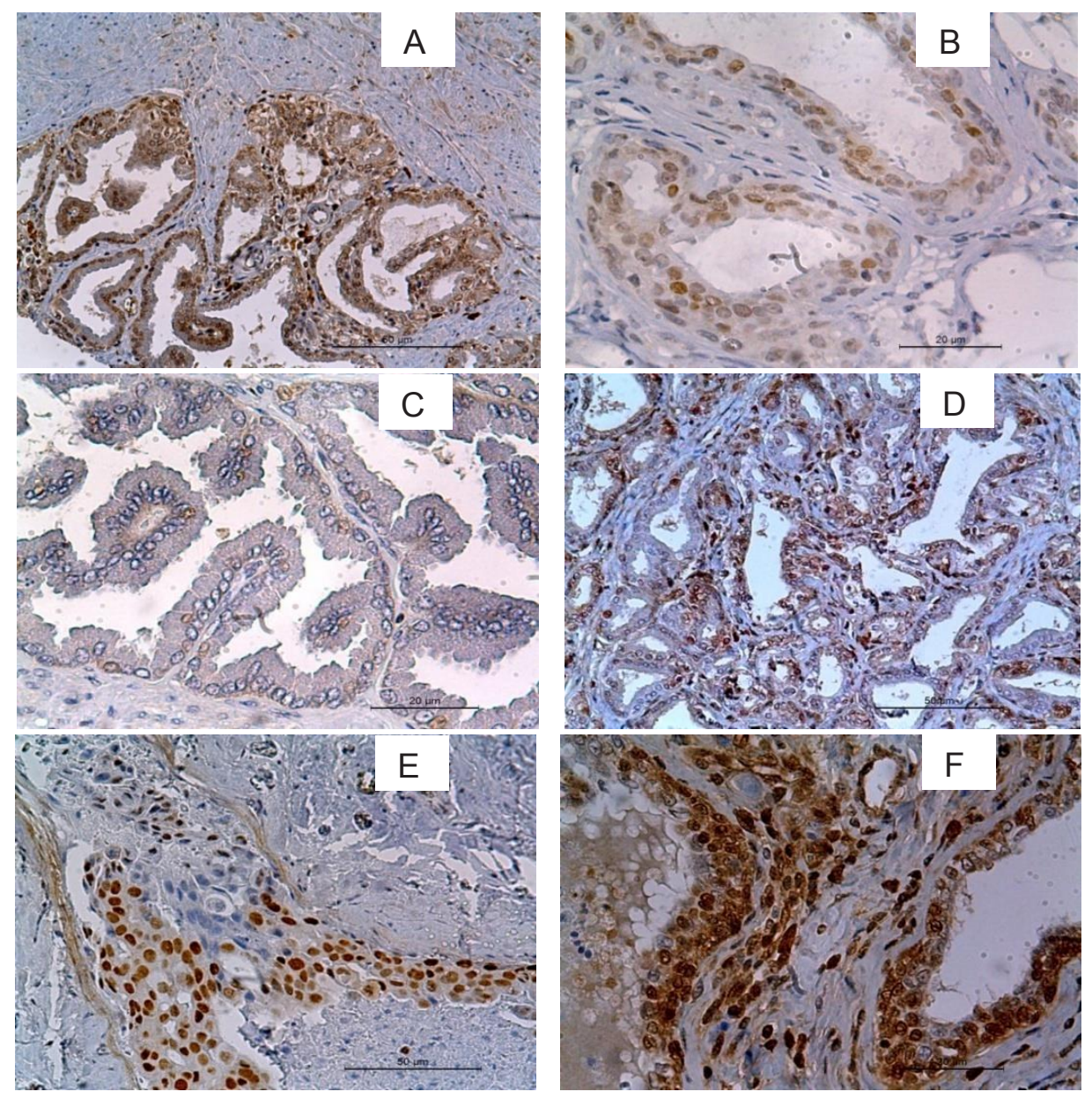

continue 
continuation
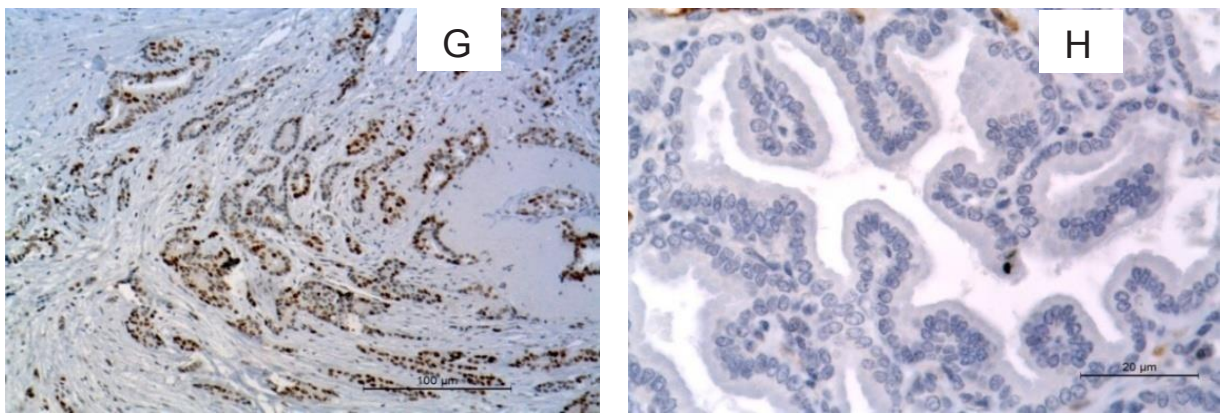

Figure 2. Photomicrography of nuclear, cytoplasmic and membrane immunostaining. A) Canine PIN tissue with score one for labeling intensity and three for number of labeled cells of cytoplasmic cyclin D1. B) Canine lymph node. Positive control of cytoplasmic cyclin D1 with score two for labeling intensity and two for number of labeled cells. C) Normal canine prostatic tissue with zero score for cyclin D1. D) Canine PC tissue with score three for labeling intensity and four for number of labeled cells for nuclear through cytoplasmic c-myc. E) Canine lymph node. Positive control of nuclear through cytoplasmic c-myc, with score two for labeling intensity and four for number of labeled cells. F) Normal canine prostatic tissue with score three for labeling intensity and four for number of labeled cells for c-myc. IHC, DAB, and HE counterstain. 200x and 400x.
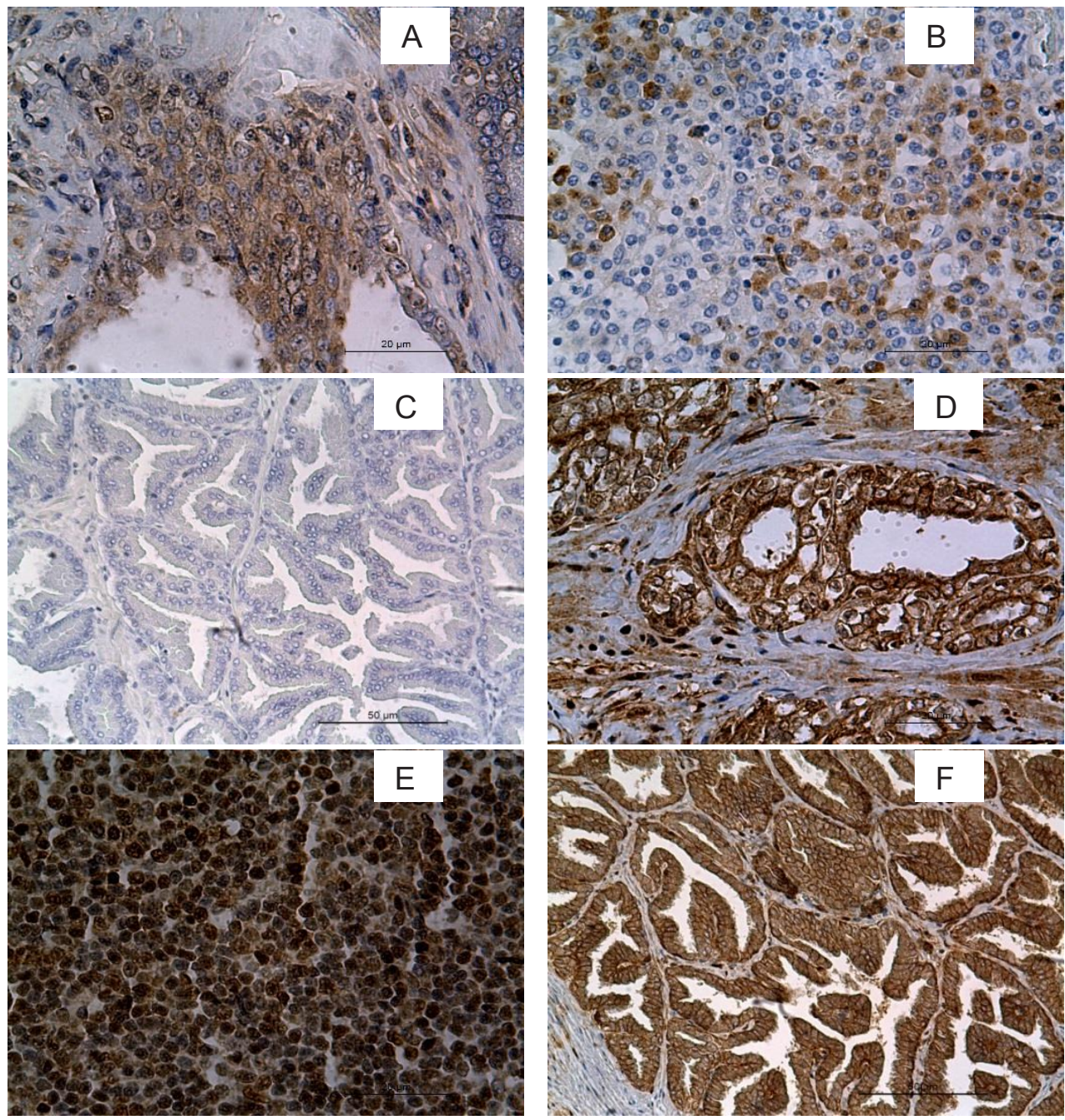
Table 2. Means of comparison between p21, p27, p53, cyclin D1 and c-myc immunostaining regarding the number of stained cells and intensity of staining cells in canine normal prostatic tissue and with BPH, PIA, PIN and PC.

\begin{tabular}{cccccccccccc}
\hline \multirow{2}{*}{ Diagnoses } & \multirow{2}{*}{$\mathbf{N}$} & \multicolumn{4}{c}{ Rank of Number of Stained Cells } & \multicolumn{4}{c}{ Rank of Staining Intensity } \\
\cline { 3 - 11 } & & p21 & p27 & c-myc & cyclin D1 & p53 & p21 & p27 & c-myc & cyclin D1 & p53 \\
\hline Normal & 15 & $36.3^{\mathrm{a}}$ & $34.4^{\mathrm{a}}$ & $54.0^{\mathrm{a}}$ & $23.0^{\mathrm{a}}$ & $16.9^{\mathrm{a}}$ & $33.9^{\mathrm{a}}$ & $31.6^{\mathrm{a}}$ & $42.5^{\mathrm{a}}$ & $21.5^{\mathrm{a}}$ & $23.0^{\mathrm{a}}$ \\
BPH & 16 & $28.0^{\mathrm{ab}}$ & $26.4^{\mathrm{a}}$ & $54.0^{\mathrm{a}}$ & $49.1^{\mathrm{b}}$ & $30.4^{\mathrm{a}}$ & $28.3^{\mathrm{a}}$ & $28.4^{\mathrm{a}}$ & $49.3^{\mathrm{a}}$ & $46.5^{\mathrm{b}}$ & $38.4^{\mathrm{a}}$ \\
PIA & 30 & $57.8^{\mathrm{ac}}$ & $60.1^{\mathrm{b}}$ & $54.5^{\mathrm{a}}$ & $61.7^{\mathrm{b}}$ & $54.6^{\mathrm{b}}$ & $55.8^{\mathrm{b}}$ & $60.4^{\mathrm{b}}$ & $63.3^{\mathrm{a}}$ & $61.4^{\mathrm{b}}$ & $55.7^{\mathrm{b}}$ \\
\hline PIN & 20 & $72.5^{\mathrm{c}}$ & $62.3^{\mathrm{b}}$ & $55.4^{\mathrm{a}}$ & $62.8^{\mathrm{b}}$ & $70.8^{\mathrm{bc}}$ & $71.4^{\mathrm{b}}$ & $60.8^{\mathrm{b}}$ & $50.8^{\mathrm{a}}$ & $61.5^{\mathrm{b}}$ & $66.9^{\mathrm{b}}$ \\
Carcinoma & 25 & $59.8^{\mathrm{ac}}$ & $67.4^{\mathrm{b}}$ & $56.0^{\mathrm{a}}$ & $57.3^{\mathrm{b}}$ & $75.2^{\mathrm{c}}$ & $64.3^{\mathrm{b}}$ & $68.6^{\mathrm{b}}$ & $53.2^{\mathrm{a}}$ & $61.6^{\mathrm{b}}$ & $68.2^{\mathrm{b}}$ \\
\hline
\end{tabular}

Similar letters in the same column are not different by nonparametric multiple comparison test for paired contrasts the relative effects with Tukey correction. ( $\mathrm{p}$ value $-\mathrm{p}<0.05$ ).

In this study, p21 was overexpressed in $40 \%$ of PC, $30 \%$ in PIN and $6.7 \%$ of PIA. It seems that malignant tissue shows high expression of 21 , which would work as a pathway to control cell proliferation in those tissues. Increased expression of p21 may lead a crucial part in growth arrest, inducing senescence or apoptosis, a mechanism which seems to protect against malignant transformation (LIN et al., 2007; MAJID et al., 2008). According to Majid et al. (2008), increased levels of p21 indicate good prognosis. So, the p21 overexpression observed in canine PC could mean tumors more controlled in terms of proliferation and growing.

Most prostates with BPH were p21 negative and those ones positives showed mild immunostaining, which could contribute to the typical cell proliferation associated with this condition in the canine prostate. According to Huang et al. (2004), prostatic tissue with $\mathrm{BPH}$ may express $\mathrm{p} 21$ due to an alteration in CDKN1A, the p21 gene. It could cause an imbalance between cell proliferation and apoptosis in the prostatic tissue, resulting in a continuous cell cycle, which influences the cell proliferation and involves the pathogenesis of $\mathrm{BPH}$.

The number of stained cells to p27 in normal prostatic tissue was different from those with PIA, PIN and PC, as well as it was different in prostates with BPH from those with PIA, PIN and PC. According to intensity of expression, there were differences in normal prostatic tissue from those with PIA, PIN and PC, as well as it was different in prostatic tissues with $\mathrm{BPH}$ from those with PIA, PIN and PC $(p<0.05$ - Table 2).

Prostate with PIA, PIN and PC showed higher immunostaining of p27 when compared to BPH and normal tissue. The opposite was reported by De Marzo et al. (1998) in human prostate with PIN and PC, which showed lower expression of p27. Once loss or decrease of p27 has been associated with cell undifferentiation, proliferation and poor prognostic (TAYLOR et al., 2010), it is prompt to think that p27 would be working as a product of one suppressor gene $(\mathrm{CDKN} 1 \mathrm{~B})$ in canine prostate tissues with premalignant and malignant lesions. Reinforcing this hypothesis, Trotman et al. (2003) have observed $100 \%$ of prostate tumors in p27 deficient mices. Wang et al. (2012) reported that overexpression of p27 in prostate with PIN may contribute to preventing and inhibiting the progression of PIN to invasive PC. Either, Wang et al. (2012) affirm that both p 27 and p53 function should be checked in the progression of PIN to invasive cancer in order to prognosis establishment.

The number of stained cells to p53 in normal prostatic tissue was different from those with PIA, PIN and PC as well as it was different in prostatic tissues with BPH from those with PIA, PIN and PC, and in prostatic tissues with PIA from those with PC. According to intensity of expression, there were differences in normal prostatic tissue from those 
with PIA, PIN and PC, as well as it was different in prostatic tissues with $\mathrm{BPH}$ from those with PIA, PIN and PC ( $<<0.05$ - Table 2).

The expression of p53 was observed in normal canine prostate, in proliferative lesions, and a higher expression in PC, as reported by Croce et al. (2011). There were differences between PIA and PC, but not between $\mathrm{PC}$ and PIN relative to the number of stained cells. These results suggest that alterations related with the $\mathrm{p} 53$ protein begin in the canine prostate with PIA and are accentuated in the canine glands with PIN and PC, reinforcing malignant potential of PIN as previously described in dogs (CROCE et al., 2011), and humans (STANGELBERGER et al., 2012). According to Stangelberger et al. (2012), the high expression of p53 in human PC and PIN has been associated with progression of disease due to higher proliferative indices and more aggressive phenotype.

The number of stained cells to cyclin D1 in normal prostatic tissue was different from those with BPH, PIA, PIN and PC. According to intensity of expression, there were differences in normal prostatic tissue from those with BPH, PIA, PIN and PC $(p<0.05$ - Table 2$)$. The number and the intensity of stained cells to c-myc antibody there were no difference according to diagnoses $(\mathrm{p}<0.05$ - Table 2$)$.

In canine prostate we observed cyclin D1 (CD1) immunostaining only in tissues with lesions $(\mathrm{BPH}$, PIA, PIN, PC). Moreover, the CD1 expression though almost mild it was more frequent in prostates with PIA, PIN and PC if compared to BPH. CD1 protein is a positive regulator of $\mathrm{G} 1-\mathrm{S}$ phase progression in the cell cycle. It binds to and activates the cyclindependent kinases Cdk4 and Cdk6 (MURAKAMI et al., 2000; COLOZZA et al., 2005; IMBODEN et al., 2009), and the low expression of CD1 is significantly associated with high expression of $\mathrm{p} 21$ protein (LIN et al., 2007; WANG et al., 2010). Also, according to Jirawatnotai et al. (2011), CD1 may play a positive role in DNA damage repair. Thus, the seeming lower expression of CD1 in association with high p21 expression could mean the slowing of cell cycle and it mild expression could represent the repairing of DNA damaged in the prostatic tissue with proliferative lesion.

There was strong positive correlation between p21 and p27 for both number of stained cells and staining intensity for normal tissue and with $\mathrm{BPH}$, PIA, PIN and PC. There was positive correlation between p21 and p53 regarding the number of stained cells in normal prostate tissue, and also the intensity of staining to PIN tissue. There was positive correlation of staining intensity between p27 and c-myc in prostates with PIA. Also, in prostates with PIN there was correlation between p53 and c-myc relative to the intensity of staining cell (Table 3).

Furthermore, there was negative correlation between c-myc and cyclin D1 for prostate tissue with PIN regarding the number of stained cells. Considering staining intensity, there was negative correlation between p27 and c-myc and between p21 and c-myc for prostate with carcinoma. That means that high values of one variable are associated the low values of the other variable (Table 3 ).

Interestingly, even though no differences based on c-myc immunostaining according to diagnosis, c-myc immunostaining was found in all normal prostates and with PIA, PIN, and PC, PIA and PIN. However, it was cytoplasmic or nuclear depending on diagnosis, being cytoplasmic in normal and with $\mathrm{BPH}$ prostates, and cytoplasmic and/or nuclear in glands with PIA, PIN and PC. It was also observed that even in low frequency, the immunostaining became stronger from PIA to PIN and from this to $\mathrm{PC}$ and also when compared to normal prostate and with BPH. These results are similar to those described by Fonseca-Alves et al. (2013) who reported c-myc immunostaining in canine normal prostate and with PIA and PC having concomitant PIN foci. These authors also observed cytoplasmic and nuclear immunostaining, but with nuclear staining only in few prostates with PC. Although the 
cytoplasmic immunostaining of c-myc is reported (FONSECA-ALVES et al., 2013), its importance at this location is controversial, since Koh et al. (2010) affirm that almost c-myc functions are based on its known nuclear action. So, considering our results for nuclear immunostaining of c-myc it seems that lesions of PIA and PIN have malignant potential and the canine PC could be less aggressive, since the increased c-myc expression in the human PC is related to tumor cell proliferation, undifferentiation of basal cells, and changes in the apoptotic pathway (KOH et al., 2010). According to Dang (2012), c-myc is overexpressed at early and late stages of development of PC and many others human cancers.

Table 3. Means of correlation between antibodies expression regarding the number of stained cells and intensity of staining of the normal canine prostate and with BPH, PIA, PIN and PC.

\begin{tabular}{|c|c|c|c|c|c|c|c|c|c|c|c|}
\hline & \multirow{3}{*}{ CORRELATION } & \multicolumn{10}{|c|}{ Diagnoses } \\
\hline & & \multicolumn{2}{|c|}{ Normal } & \multicolumn{2}{|l|}{$\mathrm{BPH}$} & \multicolumn{2}{|l|}{ PIA } & \multicolumn{2}{|l|}{ PIN } & \multicolumn{2}{|l|}{ PC } \\
\hline & & $\mathrm{R}$ & $\mathrm{P}$ & $\mathrm{R}$ & $\mathrm{P}$ & $\mathrm{R}$ & $\mathrm{P}$ & $\mathrm{R}$ & $\mathrm{P}$ & $\mathrm{R}$ & $\mathrm{P}$ \\
\hline \multirow{8}{*}{ 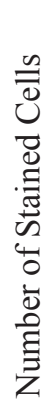 } & $\mathrm{p} 21 / \mathrm{p} 27$ & 0.841 & $<0.001^{\text {cr }}$ & 0.992 & $<0.001^{\text {cr }}$ & 0.527 & $0.043^{\text {cr }}$ & 0.528 & $0.017^{\text {cr }}$ & 0.587 & $0.002^{\text {cr }}$ \\
\hline & p21/cyclin D1 & - & - & 0.173 & 0.681 & -0.30 & 0.272 & -0.329 & 0.157 & 0.273 & 0.187 \\
\hline & $\mathrm{p} 21 / \mathrm{p} 53$ & 0.518 & $0.048^{\text {cr }}$ & 0.378 & 0.356 & -0.073 & 0.797 & 0.223 & 0.345 & 0.088 & 0.676 \\
\hline & p27/cyclin D1 & - & - & 0.201 & 0.634 & 0.170 & 0.545 & -0.123 & 0.606 & 0.201 & 0.334 \\
\hline & $\mathrm{p} 27 / \mathrm{p} 53$ & 0.325 & 0.237 & 0.375 & 0.360 & -0.019 & 0.947 & 0.090 & 0.705 & 0.265 & 0.200 \\
\hline & c-Myc/cyclin D1 & - & - & - & - & - & - & -0.446 & $0.049^{\text {cr }}$ & - & - \\
\hline & c-Myc/p53 & - & - & - & - & - & - & 0.379 & $0.009^{\text {cr }}$ & - & - \\
\hline & cyclin D1/ p53 & - & - & 0.344 & 0.404 & 0.022 & 0.938 & -0.307 & 0.187 & 0.161 & 0.442 \\
\hline \multirow{10}{*}{ 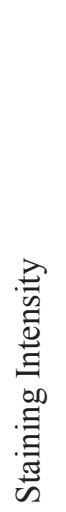 } & $\mathrm{p} 21 / \mathrm{p} 27$ & 0.732 & $0.002^{\text {cr }}$ & 1.000 & $<0.001^{\text {cr }}$ & 0.522 & $0.046^{\text {cr }}$ & 0.429 & $0.050^{\text {cr }}$ & 0.573 & $0.003^{\text {cr }}$ \\
\hline & p21/c-Myc & -0.378 & 0.165 & 0.293 & 0.482 & 0.121 & 0.667 & 0.324 & 0.164 & -0.404 & $0.045^{\text {cr }}$ \\
\hline & p21/cyclin D1 & - & - & 0.467 & 0.244 & 0.295 & 0.286 & -0.057 & 0.813 & 0.061 & 0.772 \\
\hline & $\mathrm{p} 21 / \mathrm{p} 53$ & 0.262 & 0.346 & 0.447 & 0.267 & 0.250 & 0.369 & 0.445 & $0.050^{\text {cr }}$ & -0.056 & 0.789 \\
\hline & p27/c-Myc & -0.378 & 0.165 & 0.293 & 0.482 & 0.592 & $0.020^{\text {cr }}$ & -0.058 & 0.807 & -0.586 & $0.002^{\text {cr }}$ \\
\hline & p27/cyclin D1 & - & - & 0.467 & 0.244 & 0.407 & 0.132 & -0.114 & 0.633 & -0.039 & 0.852 \\
\hline & $\mathrm{p} 27 / \mathrm{p} 53$ & 0.262 & 0.346 & 0.447 & 0.267 & 0.150 & 0.594 & 0.200 & 0.397 & 0.090 & 0.669 \\
\hline & c-Myc/cyclin D1 & - & - & 0.293 & 0.482 & 0.058 & 0.837 & 0.100 & 0.674 & 0.064 & 0.762 \\
\hline & $\mathrm{c}-\mathrm{Myc} / \mathrm{p} 53$ & -0.213 & 0.446 & -0.218 & 0.604 & -0.069 & 0.806 & 0.593 & $0.006^{\text {cr }}$ & 0.145 & 0.488 \\
\hline & cyclin D1/ p53 & - & - & 0.447 & 0.267 & 0.282 & 0.309 & 0.083 & 0.728 & 0.124 & 0.554 \\
\hline
\end{tabular}

$\mathrm{R}=$ Spearman's correlation between the antibodies; P values followed by the letters cr represents the correlation between the antibodies $(\mathrm{p}<0.05)$.

A correlation between $\mathrm{p} 21$ and $\mathrm{p} 27$ was observed in all tissues (normal, BPH, PIA, PIN and PC) relative to the number and intensity of immunostaining in canine prostates, but not between p21, p27 and cyclin D1 and c-myc. Wang et al. (2010) reported that when p21 and p27 levels are increased and cyclin D1 decreased, a good prognosis is expected. Likewise, Majid et al. (2008) reported an increase of the p21 and p27 with decrease of several types of cyclin (A2, B2, E1 and E2), but not with cyclin D1. Thus, herein our results suggest that even though there was no correlation between those proteins, the positive relation between $\mathrm{p} 21$ and $\mathrm{p} 27$ overexpression and decreasing of CD1 seems to be controlling the cell proliferation in canine prostates with proliferative disorders, mainly in $\mathrm{PC}$, which 
could explain the low incidence of canine PC in comparison with this tumor in human glands.

There was positive correlation between immunostaining of p21 and p53 in normal canine prostatic tissues, but not in prostates with proliferative lesions, except in glands with PIN regarding intensity of staining. This confirms that the expressions of p21and p53 are associated and both are active in the cell pathway where p53 induces p21in normal tissues (KIRKNESS et al., 2003; GARTEL; RADHAKRISHNAN, 2005). Thus, this known cellular mechanism of control and repair would be absent in those canine prostates with PIA and PC, enabling the cell growing, since the reduction or absence of $\mathrm{p} 21$ has been shown in cell lines of tumors lacking p53 or containing a non-functional mutant form of TP53 (STANGELBERGER et al., 2012). However, it seems that even in the presence of p53 mutant, p21 is induced and keeps its action controlling cell growth, which could justify the low development of PC in canine prostate. In prostates with PIA, the inflammatory environment could be changing those proteins expression and other $\mathrm{p} 21$ pathways would arrest cell proliferation. In this context, Yan et al. (2012) identified p21 induction independent of p53 expression in several cell types of tumors, including human breast cancer cells and canine kidney cell line. Also, in human PC, Matsushima et al. (1998) reported that $\mathrm{PC}$ with $\mathrm{p} 53^{+} / \mathrm{p} 21^{-}$phenotype showed poorer prognosis compared with those $\mathrm{p} 53^{+} / \mathrm{p} 21^{+}$, and that combination could predict the patient survival more accurately than p53 immunostaining alone, turning p21 a useful tool for interpretation of p53 IHC results.

In conclusion, the expression of p21, p27, p53, cyclin D1 and c-myc varies according to type of proliferative lesion in canine prostate. Taken together, the results of this study indicate low growth potential of the canine $\mathrm{PC}$ in the presence of $\mathrm{p} 21$ and p27 overexpression, cyclin D1 low expression and regular expression of c-myc, also with the expression of p53 mutant type. Further, the similar cell cycle progression regulators immunostaining profile presented by glands with PIA, PIN and PC, corroborate the pre-malignant potential of PIA and PIN in canine prostate.

\section{Acknowledgements}

The authors would like to express their gratitude to all members of the A.C. Camargo Cancer Center, specially to Dr. Rafael Malagoli and Carlos Ferreira Nascimento for expert technical assistance in TMA, and Suely Nonogaki for helping in immunohistochemistry.

\section{References}

BOSTWICK, D. G. High-grade prostatic intraepithelial neoplasia: the most likely precursor of prostate cancer. Cancer, New York, v. 75, n. 7, p. 1823-1836, 1995.

COLOZZA, M.; AZAMBUJA, E.; CARDOSO, F.; SOTIRIOU, C.; LARSIMONT, D.; PICCART, M. J. Proliferative markers as prognostic and predictive tools in early breast cancer: where are we now? Annals of Oncology, Oxford, v. 16, n. 11, p. 1723-1739, 2005.

CROCE, G. B.; RODRIGUES, M. M. P.; FALEIRO, M. B. R.; MOURA, V. M. B. D de.; LAUFER-AMORIM, R. Óxido nítrico, GSTP-1 e p53: qual o papel desses biomarcadores nas lesões prostáticas do cão? Arquivo Brasileiro de Medicina Veterinária e Zootecnia, Belo Horizonte, v. 63, n. 6, p. 1368-1376, 2011.

DANG, C. H. I. V. MYC on the path to cancer. Cell, Cambridge, v. 149, n.1, p. 22-35, 2012.

DE MARZO, A. M.; MEEKER, A. K.; EPSTEIN, J. I.; COFFEY, D. S.; Prostate stem cell compartments: Expression of the cell cycle inhibitor p2 $7^{\mathrm{kip} 1}$ in normal, hyperplastic, and neoplastic cells. The American Journal of Pathology, Philadelphia, v. 153, n. 3, p. 911-919, 1998.

FONSECA-ALVES, C. E.; FALEIRO, M. B. R.; LAUFER-AMORIM, R.; MOURA, V. M. B. D. de; Prostatic histological evaluation in adult not castrated dogs. Arquivo Brasileiro de Medicina. Veterinária e Zootecnia, Belo Horizonte, v. 62, n. 3, p. 10-29, 2010.

FONSECA-ALVES, C. E.; RODRIGUES, M. M. P.; MOURA, V. M. B. D. de; ROGATTO, S. R.; LAUFERAMORIM, R. Alterations of C-MYC, NKX3.1, and E-cadherin expression in canine prostate carcinogenesis. Microscopy Research and Technique, New York, v. 76, n. 
12, p. 1250-1256, 2013.

GARTEL, A. L.; RADHAKRISHNAN, S. K. Lost in transcription: p21 repression, mechanisms, and consequences. Cancer Research, Baltimore, v. 65, n. 10, p. 3980-3985, 2005.

GAVHANE, D. S.; SINGH, A.; SOOD, N. K.; GUPTA, K.; BAIG, M. R.; MUGALE, M. Immunolocalisation of c-Myc an oncoprotein of canine mammary tumors. Israel Journal of Veterinary Medicine, Front Cover DEVON REX, Raanana, v. 68, n. 2, p. 101-105, 2013.

HUANG, S. P.; WU, W. J.; CHANG, W. S. W.; WU, M. T.; CHEN, Y. Y.; CHEN, Y. J. p53 codon 72 and p21 codon 31 polymorphisms in prostate cancer. Cancer Epidemiology Biomarkers \& Prevention, Philadelphia, v. 13, n. 12, p. 2217-2224, 2004.

IMBODEN, M.; SCHWARTZ, J.; SCHINDLER, C.; CURJURIC, I.; BERGER, W.; LIU, S. L. J. Decreased $\mathrm{PM}$ exposure attenuates age-related lung function decline: genetic variants in p53, p21, and CCND1 modify this effect. Environmental Health Perspectives, New York, v. 117, n. 9, p. 1420-1427, 2009.

JIRAWATNOTAI, S.; HU, Y.; MICHOWSKI, W.; ELIAS, J. E.; BECKS, L.; BIENVENU, F. A function for cyclin D1 in DNA repair uncovered by interactome analyses in human cancers. Nature, London, v. 474, n. 7350, p. 230-234, 2011.

KIRKNESS, E. F.; BAFNA, V.; HALPERN, A. L.; LEVY, S.; REMINGTON, K.; RUSCH, D. B. The dog genome: survey sequencing and comparative analysis. Science, London, v. 301, n. 5641, p. 1898-1903, 2003.

KOH, C. M.; BIEBERICH, C. J.; DANG, C. V.; NELSON, W. G.; YEGNASUBRAMANIAN, S.; MARZO, A. M. de. MYC and prostate cancer. Genes \& Cancer, London, v. 1, n. 6, p. 617-628, 2010.

LAI, C. L.; VAN DEN HAM, R.; VAN LEENDERS, G.; VAN DER LUGT, J.; MOL, J. A.; TESKE, E. Histopathological and immunohistochemical characterization of canine prostate cancer. Prostate, New York, v. 68, n. 5, p. 477-488, 2008.

LIMA, C. R. O.; FALEIRO, M. B. R.; RABELO, R. E.; VULCANI, V. A. S.; RUBINI, M. R.; TORRES, F. A. G.; DE MOURA, V. M. B. D. Insertion of the LINE1 element in the C-MYC gene and immunoreactivity of C-MYC, p53, p21 and p27 proteins in different morphological patterns of the canine TVT. Arquivo Brasileiro de Medicina Veterinária e Zootecnia, Belo Horizonte, v. 68, n. 3, p. 658-666, 2016.

LIN, P. Y.; FOSMIRE, S. P.; PARK, S. H.; PARK, J. Y.; BAKSH, S.; MODIANO, J. F. Attenuation of PTEN increases p21 stability and cytosolic localization in kidney cancer cells: a potential mechanism of apoptosis resistance. Molecular Cancer, Philadelphia, v. 6, n. 72, p. 16, 2007.

LOPES, R. A.; CARDOSO, T. C.; LUVIZOTTO, M. C. R.; ANDRADE, A. L. Occurrence and expression of p53 suppressor gene and c-Myc oncogene in dog eyelid tumors. Veterinary Ophthalmology, Ohio, v. 13, n. 2, p. 69-75, 2010.

MAJID, S.; KIKUNO, N.; NELLES, J.; NOONAN, E.; TANAKA, Y.; KAWAMOTO, K. Genistein induces the $\mathrm{p} 21^{\mathrm{WAF} / \mathrm{CIP1}}$ and $\mathrm{p} 16^{\mathrm{INK} 4 a}$ tumor suppressor genes in prostate cancer cells by epigenetic mechanisms involving active chromatin modification. Cancer Research, Baltimore v. 68, n. 8, p. 2736-2744, 2008.

MATSUSHIMA, H.; SASAKI, T.; GOTO, T.; HOSAKA, Y.; HOMMA, Y.; KITAMURA, T. Immunohistochemical study of $\mathrm{p} 21^{\mathrm{WAF} 1}$ and $\mathrm{p} 53$ protein in prostate cancer and their prognostic significance. Human Pathology, New York, v. 29, n. 8, p. 778-83, 1998.

MURAKAMI, Y.; TATEYAMA, S.; RUNGSIPIPAT, A.; UCHIDA, K.; YAMAGUCHI, R.; Immunohistochemical analysis of cyclin A, cyclin D1 and P53 in mammary tumors, squamous cell carcinomas and basal cell tumors of dogs and cats. The Journal of Veterinary of Medicine Science, Tokyo, v. 62, n. 7, p. 743-750, 2000.

OZAKI, K.; YAMAGAMI, T.; NOMURA, K.; NARAMA, I. Prognostic significance of surgical margin, $\mathrm{Ki}-67$ and cyclin D1 protein expression in grade II canine cutaneous mast cell tumor. The Journal of Veterinary Medicine Science, Tokyo, v. 69, n. 11, p. 1117-1121, 2007.

RUBIN, M. A.; DUNN, R.; STRAWDERMAN, M.; PIENTA, K. J. Tissue microarray sampling strategy for prostate cancer biomarker analysis. The American Journal of Surgery Pathology, Hagerstown, v. 26, n. 3, p. 312-319, 2002.

SANCHEZ, I.; DYNLACHT, B. D. New insights into cyclins, CDKs, and cell cycle control. Seminars in Cell \& Developmental Biology, Amsterdam, v. 16, n. 3, p. 311321, 2005.

SFACTERIA, A.; BERTANI, C.; COSTANTINO, G.; DEL BUE, M.; PAIARDINI, M.; CERVASI, B. Cyclin D1 expression in pre-cancerous and cancerous lesions of the canine mammary gland. Journal of Comparative Pathology, London, v. 128, n. 4, p. 245-251, 2003.

STANGELBERGER, A.; SCHALLY, A. V.; RICK, F. G.; VARGA, J. L.; BAKER, B.; ZARANDI, M. Inhibitory effects of antagonists of growth hormone releasing hormone on experimental prostate cancers are associated with upregulation of wild-type p53 and decrease in 
p21 and mutant p53 proteins. Prostate, New York, v. 72, n. 5 , p. 555-565, 2012.

TAPIA, R.; HUERTA, M.; ISLAS, S.; AVILAFLORES, A.; LOPEZ-BAYGHEN, E.; WEISKE, J. Zona occludens-2 inhibits cyclin D1 expression and cell proliferation and exhibits changes in localization along the cell cycle. Molecular Biology of Cell, London, v. 20, n. 3, p. 1102-1117, 2009.

TAYLOR, W.; MATHIAS, A.; ALI, A.; KE, H.; STOYNEV, N.; SHILKAITIS, A. p2 $7^{\text {Kip1 }}$ deficiency promotes prostate carcinogenesis but does not affect the efficacy of retinoids in suppressing the neoplastic process. BMC Cancer, London, v. 10, n. 1, p. 541-552, 2010.

TOLEDO, D. C.; FALEIRO, M. B. R.; RODRIGUES, M. M. P.; DI SANTIS, G. W.; AMORIM, R. L.; MOURA, V. M. B. D. de. Histomorphological characterization of proliferative inflammatory atrophy in canine prostate. Ciência Rural, Santa Maria, v. 40, n. 6, p. 1372-1377, 2010.
TROTMAN, L. C.; NIKI, M.; DOTAN, Z. A.; KOUTCHER, J. A.; DI CRISTOFANO, A.; XIAO, A. Pten dose dictates cancer progression in the prostate. PLoS Biology, California, v. 1, n. 3, p. 385- 396, 2003.

WANG, H.; XU, Y.; FANG, Z.; CHEN, S.; BALK, S. P.; YUAN, X. Doxycycline regulated induction of AKT in murine prostate drives proliferation independently of p27 cyclin dependent kinase inhibitor downregulation. PLoS ONE, California, v. 7, n. 7, p. e41330, 2012.

WANG, Z.; LEE, H. J.; CHAI, Y.; HU, H.; WANG, L.; ZHANG, Y. C. Persistent $\mathrm{p} 21^{\text {Cipl }}$ induction mediates G1 cell cycle arrest by methylseleninic acid in DU145 prostate cancer cells. Current Cancer Drug Targets, Amarillo, v. 10, n. 3, p. 307-318, 2010.

YAN, X.; ZHANG, J.; SUN, Q.; TUAZON, P. T.; WU, X.; TRAUGH, J. A. p21-activated Kinase 2 (PAK2) Inhibits TGF-B signaling in madin-darby canine kidney (MDCK) epithelial cells by interfering with the receptor-smad interaction. Journal of Biology Chemistry, Rockville, v. 287, n. 17, p. 13705-13712, 2012. 
